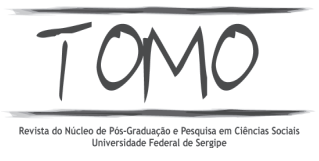

\title{
DIÁLOGOS E TENSÕES ENTRE O CATOLICISMO E A MODERNIDADE NO BRASIL
}

Péricles Andrade*

Com o avanço da secularização, as religiões entraram numa crise de plausibilidade, que é refratada de maneiras diferentes pelos vários prismas das tradições religiosas. No caso específico do catolicismo, o mundo moderno foi encarado com muito mais suspeita desde o começo, mantendo, inclusive, até a uma data recente suas defesas cognitivas contra a modernidade. Porém, após o Concílio Vaticano II (1962-1965) os ruídos de uma espantosa modernidade emergiram. Apesar das recentes medidas contrárias tomadas por João Paulo II, este Concílio marcou a face do catolicismo nas últimas décadas do século XX, principalmente pela grande vontade de mudança, atualidade e modernidade. Dentre os mais importantes resultados das reuniões de bispos do mundo inteiro, destaca-se a revisão do papel dos leigos na Igreja Católica. Enquanto anteriormente os movimentos leigos funcionavam principalmente como uma maneira de se controlar o laicato, agora a doutrina passou a ser a participação real das pessoas comuns na Igreja (THEIJE, 2002, 145). Dele emergem dois movimentos que estabelecem um diálogo entre religião e mundo: a Igreja

* Doutor em Sociologia pela Universidade Federal de Pernambuco; Professor-Adjunto I da Universidade Federal de Sergipe.

\begin{tabular}{l|ll|l|l|} 
TOMO & São & Cristóvão-SE & $N^{0} 12$ & jan./jun. 2008 \\
\hline
\end{tabular}


dos Pobres - elaboração teológica mais voltada para os problemas sociais - e a Renovação Carismática Católica, que tomou a trilha de uma renovação conservadora, mas que se abre à modernidade com o uso de técnicas de marketing e dos meios de comunicação social.

\section{A Igreja Progressista no Brasil}

A Igreja Brasileira esteve, durante um significado período, influência decisiva da Teologia da Libertação e de seus seguidores nas pastorais. Já na década de 1950 são formados os sindicatos de trabalhadores rurais, as ligas camponesas e o MEB, que contaram, inclusive, com a participação de religiosos católicos. Embora não tenham funcionado por muito tempo, eles assinalam a introdução de um novo conceito de organização leiga. Se na década de 1930 e 1940 os esforços de mobilização se voltavam para dentro e para a criação de grupos leigos especificamente católicos, com objetivos fortemente devocionais, a ênfase agora passou a ser dada à contribuição para movimentos sociais mais amplos. Cada vez mais, a idéia era formar coalizões com outros militantes - como sindicatos, ligas camponesas e grupos estudantis para alcançar objetivos comuns. Os católicos contribuiriam com sua participação nesses movimentos para uma mudança fundamental da sociedade, inspirada em suas crenças. Enquanto isso, o medo de uma revolução comunista crescia substancialmente, não só entre os donos de terras ou os detentores tradicionais do poder, mas também entre partes moderadas da sociedade. Nos anos turbulentos que antecederam o golpe militar, a CNBB tornara-se um enérgico porta-voz dos críticos (THEIJE, 2002: 144). ${ }^{1}$

No começo da década de 60 surgiu uma tendência nova, que ficou conhecida como "Esquerda Católica" (EC). Movimento estudantil católico - antiga Juventude Universitária Católica (JUC) criada por Dom Leme na década de 1930 -, radicalizou-se e muito rapidamente aproximou-se das idéias socialistas e esquerdistas. Os estudantes católicos reivindicavam a substituição da economia anárquica, baseada no lucro, por uma economia organizada de acordo com princípios humanos, objetivo este que, na prática, exigiria a nacionalização dos setores produtivos básicos. Tentando formular uma ideologia essencialmente anticapitalista e antiimperialista e em busca de uma estrutura social mais justa e mais humana, eles pedem um verdadeiro compromisso com as classes exploradas, numa verdadeira negação da estrutura capitalista. Aqui há uma radicalização das novas práticas sociais, culturais e políticas dos ativistas católicos: participação no movimento estudantil, alianças com a esquerda secular, apoio às lutas sociais e compromisso com a educação popular. 
Em abril de 1964, os militares tomaram o poder, a fim de "salvar a civilização ocidental cristã” do "comunismo ateísta”, isto é, para defender a oligarquia dominante, ameaçada pelo surgimento de movimentos sociais sob o presidente eleito, João Goulart. Em junho de 1964, a CNBB legitimou e deu sua benção ao estabelecimento de um regime militar que suspenderia as liberdades democráticas no Brasil pelos vinte anos seguintes, apesar da nova abertura defendida por João XXIII e pelos primeiros debates do Concílio Vaticano II, bem como o apoio de muitos bispos brasileiros às reformas sociais. Uma parcela da hierarquia da Igreja estava disposta a cooperar com o governo militar e favorável a um retorno gradual à ordem constitucional. Enquanto isso, o escândalo da tortura nas prisões brasileiras e o fato de que inúmeros católicos estavam entre as vítimas, começou a promover a opinião católica internacional e até mesmo a Cúria Romana: foram feitas declarações pela Comissão de Paz e Justiça do Vaticano e até pelo próprio Papa Paulo VI. ${ }^{2}$

Este quadro começou a se modificar a partir de 1968. Em primeiro lugar, a relação entre a Igreja e o Estado mudou profundamente após a instituição do Ato Institucional $n^{o} 5$ (AI-5), que suspendia os direitos dos cidadãos brasileiros. Os ativistas católicos foram um dos poucos grupos da sociedade que tomaram uma posição firme na oposição política. Cada vez mais padres e bispos se tornaram vítimas do regime militar. Eram acusados de "simpatias comunistas" e de ações subversivas. Aos poucos, a Igreja começou a erguer a voz contra as violações dos direitos humanos. Em meio as transformações políticas no Brasil e em outros países latino-americanos, o resultado regional do Concílio Vaticano II mostrou-se na Conferência de Medellín (1968), na Colômbia. Neste encontro, bispos da América Latina discutiram o documento papal

Neste novo contexto, a EC foi marginalizada e esfacelada pela repressão. Durante a década de 1970, esta esquerda teve um número limitado de seguidores e foi acusada pela hierarquia de ser contrária à sã doutrina social da Igreja. A AP se distanciou da Igreja e a maioria dos seus membros entrou para o PCB. Entretanto, nos anos seguintes, com o surgimento de uma oposição à ditadura na sociedade civil, um número cada vez maior de católicos, incluindo padres, freiras, religiosos e até alguns bispos, começaram a passar ao lado da oposição. Esta participação de militantes cristãos nas "ações subversivas" foi acompanhada de uma repressão que se tornou cada vez mais brutal contra pessoas relacionadas com a Igreja e até membros do clero, sobretudo, com o Al-5. 
Populorum Progressio, que tratava da desigualdade entre os países pobres e ricos. Os bispos traduziram o documento numa análise da desigualdade nos países pobres, constituindo, deste modo, a “opção preferencial pelos pobres” (THEIJE, 2002: 145-146).

Depois de 1968, a Igreja Católica Brasileira, apoiada no fundamento ideológico da "opção preferencial pelos pobres”, tornou-se a mais liberacionista do continente. A Igreja era porta-voz da crítica do regime. A censura de todas as publicações e a prisão e subseqüente tortura de muitos ativistas levaram a um movimento de defesa dos direitos humanos. Em outubro de 1970, duas mudanças importantes ocorreram na Igreja Brasileira: a eleição de Dom Evaristo Arns - conhecido por seu envolvimento em defesa dos direitos humanos e sua solidariedade com os religiosos presos - para Arcebispo de São Paulo. Pouco depois, a CNBB elegeu Dom Aloísio Lorscheider, que levou a Igreja a uma oposição cada vez mais aberta de crítica à ditadura militar. Em 1973, a CNBB organizou uma campanha nacional para educar o povo acerca dos direitos humanos. Dois anos depois - quando ficou claro que o governo não iria mudar suas práticas - essa campanha desenvolveu-se numa rede de Comissões de Justiça e Paz, com comitês em diferentes regiões do país e grande apoio internacional. Igualmente no início da década de 1970, a Igreja publicou dois importantes estudos críticos sobre o modelo econômico do governo. A luta pela terra e a posição marginalizada da população indígena do Brasil levou à fundação da Comissão Pastoral da Terra (CPT) e do Conselho Missionário Indígena (CIMI). Tanto a CPT quanto o CIMI funcionavam sob a proteção da CNBB, que os defendia contra a supressão da ditadura e ambos ainda estão ativos (THEIJE, 2002: 146-147).

Aos poucos a Igreja surge aos olhos da sociedade civil e dos próprios militares como o adversário principal do estado autoritário. Vários movimentos sociais em defesa dos direitos humanos ou de sindicatos de trabalhadores ou camponeses encontram abrigo na Igreja. Através da voz dos bispos, a Igreja criticava, de uma maneira cada vez mais direta e explícita, as violações de direitos humanos e a ausência de democracia. Mas não era só isso: denunciava também o método de desenvolvimento imposto pelos militares, seu programa de "modernização" em sua totalidade, considerando-o desumano, injusto e baseado na opressão social e econômica dos pobres. O papel político dos sacerdotes católicos se tor- 
nou tão visível que Nelson Rodrigues formulou um novo tipo: o "padre de passeata" (apud. CASTRO, 1997: 144).

Esta nova postura levou a Igreja Católica à aposta na secularização, aproximando-se de diversos modos da modernidade secular. Os setores progressistas católicos acreditavam em que a secularização ocorreria sem a fuga da observância religiosa, uma vez que a religião se adaptaria à razão secular. Para um mundo secularizado propõe-se um catolicismo despido de misticismo e irracionalidade. O progresso econômico e a transformação política transcorreriam concomitantemente com o amadurecimento religioso da massa católica, aferrada por ignorância, ao misticismo religioso e devocional. Desta forma, os pobres foram conclamados ao engajamento social, à ação política e à busca de conhecimento científico para entrar no jogo político moderno. De acordo com Carlos Alberto Steil, a aposta na secularização significou a adesão da Igreja ao jogo político e simbólico que se trava no Ocidente desde o século XVIII, quando a narrativa moderna e secular começa a se tornar plausível através da conquista de um número crescente de adeptos (STEIL, 1998: 63-65).

Desta Igreja Progressista surgem em diversos países da América Latina nos anos de 1960 as Comunidades Eclesiais de Base (CEBs). Cada vez mais o diálogo com a modernidade é reforçado. A Igreja Católica redefine sua orientação naquilo que afeta o dia-a-dia do católico, não somente em termos ritualísticos e da doutrina espiritual, mas, sobretudo no que se diz respeito à maneira como o cristão deve se colocar no mundo profano. Participaram das primeiras CEBs muitos líderes das ligas camponesas e de sindicatos rurais, do MEB e da AC. As CEBs logo proliferaram também pelas cidades. Há aí um duplo movimento: o da militância católica de esquerda e o da própria Igreja que procura atualizar-se no mundo. As CEBs significaram uma mudança efetiva na prática pastoral, com inequívoca abertura para as questões sociais, gerando, inclusive, mecanismos de formação de militância político-partidária, em que ficou selado o compromisso da “opção preferencial pelos pobres” (PRANDI, 1998: 97-98). O fator marcante na renovação da Igreja que emergiu com as CEBs está na participação efetiva dos leigos na vida eclesial com necessária perspectiva de transformação social. Através das CEBs assistência da Igreja visava ajudar os pobres a se tornarem conscientes de sua posição na sociedade brasileira (THEIJE, 2002: 46-47). 
O surgimento dessas comunidades nas periferias urbanas teve como contexto a carência da população, a distância dos centros de poder público e eclesiástico, a ausência quase permanente de padres e a aliança entre motivação religiosa e manifestações por melhoria nas condições de vida local. São nessas circunstâncias que os leigos vão, aos poucos, assumindo a liderança, tanto nas celebrações como nas lutas comunitárias. Na visão deste catolicismo, sob nítida influência do marxismo, o pecado é social e chama-se capitalismo. No lugar do tradicional opositor sobrenatural ("o velho diabo") esse catolicismo coloca a classe social concreta: o mal é a burguesia e seu sistema econômico de exploração. O pecado é a exploração do homem pelo homem e a medida do pecado tem nome: a mais-valia marxista (PRANDI,1998: 100).

A Igreja dos Pobres teve grandes aspirações. O objetivo último era exercer influência sobre os indivíduos e a sociedade, por meio do processo de conscientização. Foi apresentada uma interpretação diferente da Bíblia e das doutrinas do catolicismo. A nova forma de organizar os leigos em comunidades de base e a interpretação renovada do evangelho eram maneiras de realizar uma transformação social e política da Igreja e da sociedade. A idéia principal do projeto da Igreja dos pobres era de despertar a consciência política. Os liberacionistas aplicaram esta expressão à sua abordagem, que promovia a leitura da Bíblia "da perspectiva daqueles que a lêem". A retórica do catolicismo liberacionista dava ênfase ao conhecimento e à racionalidade como ferramentas necessárias para se formar uma idéia do progresso social e da responsabilidade individual no projeto de criação do Reino de Deus na terra (THEIJE, 2002: 72-76).

Este catolicismo definia-se num feixe de relações, num conjunto de oposições e interesses que compõem o campo religioso e político latino-americano nos anos 1960 e 1990. Neste momento, a Igreja dos Pobres alcança uma existência histórica duradoura e um conteúdo significativo. Como destaca Carlos Alberto Steil, esta igreja se opõe à Igreja Institucional, comprometida com o processo colonizador e com o status quo. Ao contrário, elabora-se uma igreja que pensa pela base, articulada no movimento popular e voltada para a libertação dos oprimidos, em contraposição a uma igreja de massa, composta de uma multidão heterogênea e dispersa, sem inserção eclesial ou compromisso político com a "causa dos pobres" (STEIL, 1998: 61).

O raciocínio compreendia a idéia de que para se edificar o Reino de Deus na terra, os católicos deveriam começar a trabalhar em seu próprio 
ambiente cotidiano. Os pobres deveriam assumir a vanguarda deste movimento, pois são leais a Deus por sua unidade e fraternidade. As bases teológicas foram formuladas na Teologia da Libertação, que se diferencia em três pontos da teologia do catolicismo tradicional. Em primeiro lugar, a teologia não pode ser separada do contexto socioeconômico e do político. Segundo, esta teologia sustenta a premissa de que Deus faz "uma opção preferencial pelos pobres”. Por fim, ela é marcada pela idéia de que a salvação deve ser encontrada nesta vida: não é um prêmio a ser obtido após a morte. Os teólogos consideravam as comunidades de base como o meio mais adequado para se criar um contexto em que os católicos pobres pudessem desenvolve uma consciência da situação política e social de seu país e traduzi-la numa adequada ação política e social. A consciência social era o caminho da salvação. A religião era vista como uma fonte de mudança cultural, social e política. Inspirados em leituras da Bíblia críticas em relação à estrutura social, os pobres seriam emancipados para se filiarem aos partidos políticos e aos sindicatos e para exigirem serviços e infraestrutura dos governos locais, fazendo assim a sua parte na criação de uma sociedade justa “aqui e agora” (THEIJE, 2002: 23-24).

Ainda segundo Steil, esta igreja batista exigia dos agentes religiosos a crítica da própria instituição, tanto em relação ao seu compromisso histórico com as elites do país, quanto ao lugar marginal que os pobres sempre ocuparam na igreja, embora constituíssem a sua base de sustentação social e política. Esta autocrítica fez com que padres e freiras ligados aos movimentos sociais fossem viver em vilas e favelas dos centros urbanos, formando então os agentes religiosos inseridos (STEIL, 1998: 62). ${ }^{3}$

Ao estudar a recepção das idéias da Teologia da Libertação na Diocese de Garanhuns, Pernambuco, a antropóloga Marjo de Theije ressalta que um capítulo importante desta Diocesee começou com a chegada de três frades franciscanos à cidade de Paranatama - um acontecimento que se revelaria um grande incentivo para toda a diocese. Esses três frades tinham idéias muito liberacionistas, e embora num primeiro momento a população da cidade demonstrasse muita hesitação, eles conseguiram introduzir idéias e práticas religiosas liberacionistas. Chamavam a si mesmos de "irmãos", pois acreditavam que a palavra "frei" os distanciava do povo, e queriam expressar sua "fraternidade" com os pobres. Viviam numa casa simples, entre os pobres. Seu trabalho pastoral consistia em viver e trabalhar com o povo, e aos poucos introduzir um jeito novo de crer e de ler a Bíblia, sempre tentando estabelecer uma ligação entre os textos religiosos, o dia-a-dia e a situação socioeconômica dos pobres. Na época, seu estilo de vida e conteúdo de seus sermões representaram um corte agudo em relação ao passado (THEIJE, 2002: 153-154). 
A Igreja Católica Brasileira mostrou-se, então, como uma das mais progressistas de toda a América Latina, tornando-se, inclusive, modelo para os países do Terceiro Mundo. Entretanto, a partir dos anos oitenta, verifica-se um processo de crítica e esvaziamento da Igreja dos Pobres. Diversos aspectos podem ser mencionados. Primeiramente, a política de "reestruturação conservadora”, promovida pelo alto controle institucional da Igreja. Esta restauração se deu a partir do pontificado João Paulo II (1978). Nos dois primeiros anos este manteve um relacionamento amistoso entre Vaticano e Igreja Popular. Mas, nos anos posteriores o Papa tomou medidas contrárias: trocas de bispos (nomeação de bispos não-progressistas), intervenção na formação de presbíteros (seminários vigiado e alguns fechados), "reparoquialização" (divisão de grandes e progressistas dioceses e paróquias), desautorização da Teologia da Libertação e livros censurados. Com o "retorno a grande disciplina” proposto pelo Vaticano há um reforço do controle de corte paroquial administrado pela hierarquia e conseqüentemente pelos padres sobre os leigos. Esta reparoquialização significou a adequação da pastoral popular ao catolicismo institucional e tradicional, voltando-se mais para os ritos sacramentais e questões administrativas, em detrimento do engajamento político (PRANDI, 1998: 104-115).

Em segundo lugar, o refluxo dos movimentos sociais, em geral provocado pela queda do Leste Europeu, a crise teórica da esquerda e a ausência de alternativa para a mudança social. Segundo Steil, se no contexto dos anos 1970 e 1980 os intelectuais da Igreja traduziam o conteúdo religioso em termos revolucionários, inserindo a Teologia da Libertação numa narrativa meta-histórica que detinha a hegemonia do campo ideológico neste momento, no final dos anos 1980 e 1990, assiste-se a uma crise que atinge as esquerdas e, desta forma, a Igreja dos Pobres (STEIL, 1998: 65-66). Acrescenta-se a isto a perda da força mobilizadora da opinião pública. ${ }^{4}$

4 "Produz-se com isso uma diminuição de sua visibilidade social, deixando de ocupar o espaço que havia adquirido na imprensa e no meio acadêmicos dos anos 70 e 80 . Esta diminuição de reconhecimento público reflete-se no interior da própria instituição e pode ser medida inclusive pelo mercado editorial que, a partir dos anos 90, restringe consideravelmente as publicações sobre a Teologia da Libertação e as Comunidades Eclesiais de Base" (STEIL, 1998: 66). 
O terceiro aspecto está relacionado ao processo de desmobilização da sociedade brasileira, que coincidiu com a transição democrática, convergido ao enfraquecimento da Igreja Popular (LOVY, 2000: 31). Nos bairros periféricos de atuação das CEBs se verifica a partir da segunda metade da década de 1980 uma evidente desmobilização popular, principalmente com a ascensão de outros atores sociais, como as ONGs, os sindicatos e os partidos políticos.

Em quarto lugar, uma certa crise do catolicismo devido à forte concorrência com outras opções religiosas, provocando grande evasão de fiéis. Nesse contexto de conversão, o catolicismo das CEBs não tem como enfrentar a concorrente, pois padece das conseqüências advindas de sua concepção de indivíduo e sociedade que dá prioridade ao coletivo, em detrimento da individualidade, tão valorizada na sociedade contemporânea, mesmo quando se trata da própria concepção de fé (LOVY, 2000: 102-103).

Vale acrescentar que apesar da grande quantidade de CEBs no país (cerca de 80 mil em meados dos anos 1980), elas não mobilizaram tantas pessoas como se pensava e anunciava. A participação local efetiva sempre foi relativamente pequena. Isto pode ser atribuído, dentre outros aspectos, ao distanciamento entre os agentes de pastoral, treinados em reuniões elitistas de formação bíblica, teológica e política, e a base. Algumas lideranças de base tinham dificuldades em acompanhar o universo cultural popular, criticando-o como conservador, passivo, paternalista, além dos traços ligados ao catolicismo tradicional, como a reverência aos padres e um certo lado místico. Do lado dos fiéis, as reclamações atingiam o excesso de burocratismo (excesso de reuniões), radicalismo político e pouca atenção às questões espirituais: "muita política e pouca religião"; "muita reunião e pouca missa" ${ }^{5}$. Desta forma, no campo católico

\footnotetext{
Além destes, outros fatores são apontados na explicação da crise da postura popular: o isolamento provocado pelo radicalismo diante da burguesia; o distanciamento entre militantes e base; a ausência de organização em âmbito nacional como efeito de um certo espírito basista; o deslocamento da Igreja fora do centro de oposição ao governo, etc. (PRANDI, 1998: 102). O estudo de Marjo de Theije, intitulado Tudo o que é de Deus é bom: uma antropologia do catolicismo liberacionista em Garanhuns, discute a recepção da Teologia da Libertação na Diocese de Garanhuns. Ele permite a compreensão dos limites deste modelo de catolicismo. Primeiramente, a antropóloga analisou até que ponto
} 
desde o final da década de 1980, setores da pastoral popular começaram a difundir uma autocrítica relativa ao racionalismo pastoral, a hiperpolitização do discurso da Teologia da Libertação e a redescoberta da gratuidade da experiência da fé e de partilha. O tom geral é o de uma sensibilidade do discurso teológico. Paralelamentente, cresceram em espaço e importância os movimentos teologicamente conservadores, de base internacional, diretamente apoiados pelo Vaticano. Com sua ênfase quase exclusiva na experiência religiosa individual e sua preocupação com a perda de membros para outras religiões afro e pentecostais, esses movimentos ganharam espaço no refluxo das pastorais (BURITY, 1997: 41).

\section{A Renovação Carismática no Brasil}

A Renovação Carismática Católica (RCC) se enquadra nestas características apontadas por Joanildo Burity. Movimento leigo nascido nos EUA no ano de $1967^{6}$, a RCC adotou desde seu início vigorosa estratégia de aderência à estrutura eclesiástica da Igreja, conquistando paróquias e

a campanha do catolicismo liberacionista mudou profundamente a estrutura religiosa do catolicismo da paróquia de São Vicente. Percebeu-se que foi introduzido um modelo novo de organização para o laicato. A nova estrutura, porém, não substituiu completamente as velhas formas de organização leiga. Ao invés de representar uma ruptura com o passado, as comunidades de base tornaram-se o padrão de organização leiga. Mas, ao mesmo tempo, elas não ocuparam o lugar de outras formas. Os leigos, inclusive, não tinham de escolher entre um ou outro: muitos membros de CEBs combinam sua participação nos grupos de base liberacionista com filiação a associações que vêm de outros tempos e de outra orientação ideológica, como a Renovação Carismática (THEIJE, 2002: 204-205).

$6 \quad$ "No outono de 1967 cerca de trinta leigos católicos, membros do corpo docente da Universidade Duquesne em Pittsburgh reuniram-se em retiro espiritual para um período de oração profunda e discussão acerca da vitalidade da sua vida religiosa. Insatisfeitos com seu estilo de vida, com suas preocupações acadêmicas e sobretudo com suas experiências religiosas, buscavam uma forma de renovação espiritual que viria a afetar drasticamente a própria Igreja. Os participantes desse retiro tinham contato com diferentes grupos avivados protestantes e desejavam experimentar a transformação que o Espírito Santo podia operar nas pessoas. Sentiam que o aprofundamento da vida espiritual que podia resultar simplesmente da ação humana, o que sempre deixaria cada um sentir-se órfão invadido pelo vazio e pelo desânimo. Acreditavam que é o espírito que renova a face da Igreja e do mundo, por meio de sua ação nas pessoas. Enquanto rezavam na capela, teria ocorrido um verdadeiro Pentecostes renovado. Uns começaram a falar em línguas, outros receberam o dom da profecia ou do conhecimento. A experiência teria operado neles uma profunda transformação espiritual, dando-lhes uma nova consciência do amor de 
bispados. Seu crescimento foi tão rápido que um ano após sua fundação foi realizado um congresso nacional que conseguiu reunir centenas de pessoas. Logo se fez o primeiro congresso internacional e muitos nacionais pelos mais diferentes países. A Renovação se alastrava aparentemente sem maiores obstáculos. Em 1974, no segundo congresso internacional, participaram mais de trinta e cinco mil pessoas, vindas de 35 países. Estima-se que nessa época o movimento possuía cerca de oitocentos mil membros pelo mundo (PRANDI, 1998: 64).

A emergência da Renovação Carismática - assim como da Teologia de Libertação - deu-se a partir da renovação litúrgica e bíblica; da revisão da função do leigo no mundo e na Igreja; da procura de novas relações entre a Igreja, sociedade moderna e outras religiões. Um dos efeitos desse aggiornamento resultou nas diferentes modalidades de associações e agrupamentos dos leigos na Igreja, tais como Equipes de Nossa Senhora, Encontros de Casais em Cristo, Comunhão e Libertação, Cursilhos de Cristandade, Opus Dei, Focolares, Schönstatt, Neucatecumenais. Com esta tendência a RCC teve sua legitimidade confirmada pelo reconhecimento internacional do Papa Paulo VI em 1973. Com a benção papal, com a leitura da Bíblia, o zelo missionário, a valorização dos dons e carismas, o incentivo à glossalia, o culto ao Espírito Santo, à Virgem Maria e tendo como fundamento a oração, o "pentecostalismo católico" (primeira denominação do movimento) espalha-se pelos cinco continentes (CARRANZA, 2000: 27-28).

Em relação à sua instituição no Brasil, Brenda Carranza destaca duas experiências embrionárias feitas por padres estrangeiros. Primeiramente, através do Pe. Haroldo Joseph Rahm em 1969, na Vila Brandina (Campinas-SP), origina-se um movimento que posteriormente seria identificado com a RCC. Sua primeira raiz fincou-se na experiência dos cursos de

Deus, um profundo desejo de louvar a Deus e de ser testemunha de Cristo ressuscitado. Dois dos participantes, ligados aos Cursilhos de Cristandade, Ralph Martin e Steve Clark decidiram ali dedicar suas vidas a Deus, fundando a comunidade Mundo de Deus, em Ann Arbor, cidade universitária localizada no estado de Michigan, que então reunia católicos e protestantes, estes em minoria. Informal no início, a comunidade foi expandido-se e estruturando-se. Além do tempo dedicado à oração, havia os serviços de visita a hospitais, prisões etc." (PRANDI, 1998: 63-64.) 
Treinamento de Lideranças Cristãs (TLC), os quais tinham como público alvo os jovens e, por objetivo suscitar uma experiência forte de iniciação na vivência espiritual. A TLC teve como finalidade a formação do espírito comunitário nos jovens e a purificação da vida, que aconteceu através de encontros catequéticos de final de semana. Estes se desenvolveram com uma estrutura e temáticas próprias, como doutrina da Igreja, ação social, vocação cristã e inserção na comunidade. No nascimento da RCC, encontra-se também o Pe. Eduardo Dougherty. Com seu espírito de empreendimento, sendo fundador da Comunidade Aliança com Jesus Te Ama, da Associação do Senhor Jesus e do Centro de Produção Televisiva Século XXI, Pe. Eduardo tem se destacado na expansão católica nos meios de comunicação social (CARRANZA, 2000: 30-33).

Além do impulso destes dois sacerdotes, Carranza destaca mais três fatores. A publicação do livro Sereis Batizados no Espírito (1973) foi uma alavanca para a difusão da RCC no Brasil, sobretudo, porque a obra teve aprovação da CNBB e prefácio de Dom Antônio Maria Alves de Siqueira, então, bispo de Campinas. Com o prefácio deste bispo conservador, a resistência de alguns setores católicos foram vencidas. A partir deste livro e dos incontáveis retiros e seminários realizados com a presença de sacerdotes norte-americanos, a RCC difundia-se e afirmava-se no território brasileiro. Também ajudou na consolidação da Renovação Brasil o gesto simbólico de imposição de mãos. A imposição de mãos consiste na impostação das mãos sobre a cabeça daquele que será enviado a evangelizar, portanto, a assembléia reconhece sua missão e legitima suas ações. Graças a este gesto, os carismáticos avançaram num contexto de ditadura militar, de pobreza e influência norteamericana. Enfim, a raiz da RCC finca-se nos Cursilhos de Cristandade, que foram fundados na Espanha em 1949, pelo Monsenhor Juan Hervás. É um movimento de profissionais católicos que surge como uma nova forma de organização dos quadros médios da liderança leiga na Igreja Católica, na década de 60. É desse modelo de formação e engajamento de lideranças que em Campinas a RCC recruta seus membros para comporem o futuro quadro de dirigentes. São eles que darão o perfil de classe média que caracterizou até recentemente a Renovação (CARRANZA, 2000: 33-44). 
A RCC é um movimento de leigos, iniciado e liderado por eles. O laicato controla os cargos de coordenação em âmbitos paroquial, diocesano, regional e nacional; coordenam os grupos de oração, organizam os encontros, seminários e congressos que reúnem membros de vários grupos de oração. Porém, deve se destacar que o clero também sempre teve um papel importante. Bispos e padres foram sempre assessores, coordenadores adjuntos ou responsáveis pelo Movimento perante a igreja. Ou seja, de alguma forma, sempre houve tutela.

Seus participantes, na sua grande maioria, têm renda e escolaridade maiores do que a média dos demais católicos. A RCC atinge um estrato específico da sociedade. Do ponto de vista da trajetória religiosa, também, percebe-se que a maioria dos carismáticos é vinda da própria Igreja Católica. São pessoas que já tinham profundos vínculos com o catolicismo, especificamente com o culto mariano e sua doutrina. $\mathrm{O}$ discurso carismático veio recuperar um público de classe média que estava perdido num tiroteio de opções religiosas. Por um lado uma Igreja dos Pobres, muito ligada às aspirações políticas da esquerda e com um discurso racionalizado e secularizado. Por outro lado, o pentecostalismo que encontrava discursos mais macios aos ouvidos, mas distantes da tradição católica, principalmente aqueles da classe média. Havia certa dificuldade católica de inserção num território mais pobre, o que leva a uma preferência dessa população pelos pentecostais. Desta forma, o movimento carismático logrou um especial apelo às camadas médias urbanas. Diferentemente dos pentecostais, a RCC tinha dificuldades de aproximação das classes populares por três razões: 1) não ter sido capaz de resolver sua relação com as CEBs e seu catolicismo; 2) suas lideranças e organização não contemplavam a figura do pastor pentecostal, capaz de encontrar mil ardis doutrinários e rituais para conduzir a conversão; 3) não ter sido capaz de se apresentar como alternativa que rompe para repor, isto é, ela não é capaz de fornecer o sentido da conversão (PRANDI, 1998: 159-169).

Apesar de seu forte caráter social de classe média, aos poucos os carismáticos estão conseguindo atingir amplos setores da população, quebrando as resistências apontadas. Com o processo de esvaziamento da Igreja Popular, descrito anteriormente, a RCC cresce nos lugares, inclusive, de atuação das CEBs. Diferentemente do abismo existente entre 
as lideranças batistas e os fiéis, os líderes carismáticos vêm conseguindo afirmar a identidade local, superando constrangimentos de preconceitos, rompendo com padrões conservadores e reunindo pessoas com entusiasmo, principalmente nos cenáculos e show-missas. Aqui não há grande distinção entre os brasileiros que são levados à RCC ou às igrejas pentecostais de cura divina. Ambos trabalham com interesses, problemas e necessidades muito semelhantes, quando não iguais. Ricos, pobres, católicos carismáticos, pentecostais, homens, mulheres, todos procuravam assistência espiritual e material; paz, melhoria nos relacionamentos pessoais e nos problemas de adaptação e identidade; curas de males físicos e mentais, melhorias financeiras etc. Isto aproxima os carismáticos dos pentecostais, processo descrito por Peter Berger como padronização e diferenciação marginal entre as instituições religiosas. Na medida em que as "necessidades" religiosas de certas camadas de fiéis, são semelhantes, tais instituições, ao atendê-las, tenderão a padronizar seus bens simbólicos de acordo com elas, dando pouco ênfase às divisões confessionais tradicionais (BERGER, 1985: 159).

Apesar das semelhanças com os pentecostais, Reginaldo Prandi, Rita de Cássia Telles e José Américo Justo apontam algumas diferenças. Primeiramente, enquanto os pentecostais fazem da cura o mais propalado elemento da pregação, da igreja à televisão, a cura carismática aparece sempre num contexto pessoal mais abrangente. Para o seu seguidor a mudança se dá por meio da internalização da palavra. Aqui as pessoas precisam ser "renovadas", ao passo que para o pentecostalismo elas dependem da "libertação dos espíritos imundos". Uma segunda diferença se refere aos discursos, que se dirigem a públicos diferentes. O discurso é mais "popular", mais direto, sem rodeios, no caso pentecostal é mais elaborado quando carismático, portanto, mais a gosto das classes mais favorecidas, em geral mais escolarizadas e mais sensíveis a discursos mais abstratos. A terceira diferença se dá com adesão. Para o fiel isso significa minimamente alguma mudança de mentalidade, a incorporação de conceber as relações entre os diversos planos da vida, a interiorização de padrões e normas de conduta, a modelagem de comportamentos. Em confronto com outras concepções religiosas, a RCC é reacionária, pois propõe um retrocesso tanto no campo da intimidade, quanto na esfera da 
vida pública. Seu programa defende e apresenta uma moralidade tradicional centrada na família, na sexualidade e nos costumes estreitos da vida quotidiana. As diferenças entre carismáticos e pentecostais centram-se no culto à Maria. Para os católicos é a Santa Mãe de Jesus, da Igreja e de todos os cristãos, digna de todos os louvores; para os protestantes, uma mulher que recebeu uma graça especial e que deve ser lembrada como um exemplo de conduta, não mais. Movidas por sua ânsia de renovação espiritual, os carismáticos fomentam o culto à Nossa Senhora, colocando-se como premissa insubstituível na salvação dos homens. Com seu apego à Maria, cria-se uma marca explícita de separação entre pentecostais e carismáticos. Os segundos são pentecostais, mas com Maria (PRANDI, 1998: 125-142).

As estratégias da Renovação Carismática centram-se nos grupos de oração, nos cenáculos, nos rebanhões e barzinhos, na formação de comunidades e na ofensiva nos meios de comunicação, que será discutida com mais detalhes numa seção específica. Os grupos de oração são a base da vida carismática e constituem-se em grupos semanais que procuram a renovação espiritual dos participantes, complementando a vida sacramental dos fiéis. Esses momentos se baseiam em orações sob várias formas: louvor, ação de graças, orações contemplativas, orações em línguas, petições de graça e cura; os cânticos, que são uma forma de oração; o silêncio; o exercício dos dons carismáticos; a leitura da Bíblia; os testemunhos e as partilhas. Nesses grupos, as pessoas podem vivenciar as mais diversas formas de adoração e louvor: cantar, pular, extravasar as tensões, trocar calor. Além desses grupos, os carismáticos se reúnem em cenáculos (grandes encontros anuais que acontecem em lugares públicos ou de grande visibilidade) e outras programações - como retiros de aprofundamento espiritual, vigílias de oração e louvor, reuniões de cura, entre outros (PRANDI,1998: 66).

O cenáculo é uma experiência de oração que dura um dia, constituindo-se em verdadeiro megaevento, tanto pela inversão de tempo e recursos, quanto pela quantidade de pessoas que se concentram em estádios de futebol, ginásios, sambódromos ou em locais descampados. Nos cenáculo, participam os pregadores oficiais da RCC e as bandas de músicas religiosas mais cotizadas dentro do próprio movimento; há lança- 
mento de produtos religiosos, além de acontecerem curas físicas e espirituais, milagres, oração em línguas e celebrações eucarísticas. Tais eventos apresentam um duplo movimento: atraem os católicos afastados (apresentando um catolicismo vigoroso) e oferece um serviço religioso de massas que favorece o trânsito religioso. Graças aos cenáculos, a RCC adquire visibilidade pública e amplia sua plataforma de ação, penetrando na classe pobre e popular, tornando-a parte de sua clientela, mas não a incorporando ao movimento. Por outro lado, os cenáculos aproximam os católicos dos pentecostais, especificamente da IURD (CARRANZA, 2000: 52-53).

O rebanhão, encontrão ou simplesmente retiro são eventos espirituais preparados como alternativa ao carnaval. Durante quatro dias, os jovens são motivados a participar de orações de louvor, pregações, eucaristias e de muita animação musical. Esses eventos obtêm uma grande aceitação, sobretudo entre jovens da periferia, principalmente nos chamados barzinhos de Jesus. Através de músicas cantadas em ritmo de rock, samba e heavy metal e com inspiração na música Gospel, os jovens são convocados para rezarem e louvam a Deus festivamente. Além de serem espaços de socialização onde as pessoas comem, bebem, cantam e dançam com Jesus, são oportunidades de doutrinação e catequese para os jovens. As bandas no âmbito da RCC constituem-se num elemento de coesão do grupo de jovens e reforçam sua identidade carismática (CARRANZA, 2000: 54-55).

A quarta estratégia carismática constitui as Comunidades de Aliança e as Comunidades de Vida. As primeiras consistem em agrupamentos de pessoas casadas, solteiras e profissionais que fazem compromissos privados ou votos nos conselhos evangélicos de pobreza, castidade e obediência. As segundas são grupos com vínculos fortes de autocontrole e comunhão de bens, e buscam reconhecimento canônico em Roma. É a partir das comunidades de alianças que na RCC criam-se muitas fundações e associações, através das quais é possível captar recursos financeiros, nacionais e internacionais e possuir bens (CARRANZA, 2000: 62-63).

Por fim, a RCC se estrutura a partir de inúmeras secretarias que no seu conjunto atingem todas as dimensões sociais, litúrgicas, eclesiais, familiares, espirituais, lúdicas, políticas e informativas que poderiam demandar seus membros. Dessa forma, a RCC se constitui numa socie- 
dade dentro da sociedade e uma igreja dentro da Igreja Católica, o que poderia ser caracterizado como uma sociedade inclusiva. Ela parece preencher todas as necessidades de seus membros e se auto-abastece, buscando ser a totalidade referencial de seus seguidores. De tal forma que essa totalidade referencial pode levar o membro da RCC a um encasulamento, isto é, dispondo de todos os serviços que a estrutura lhe oferece, ele não precisa sair do Movimento para a sociedade. Portanto, não parece estar muito longe de outras propostas de neocristandade da Igreja Católica, na tentativa de retomar a hegemonia religiosa que outrora a sustentou (CARRANZA, 2000: 60).

Em termos teológicos, os carismáticos defendem que a renovação espiritual é fruto da importância que nela têm os carismas ou dons do Espírito Santo, que se constituem em dádivas de Deus e devem ser usadas por aqueles que tiveram o privilégio de recebê-los. Para ser membro dessa ala do catolicismo é preciso estar vivendo em relacionamento íntimo com a Santíssima Trindade, participando sempre de uma comunidade de oração. Seus praticantes acreditam em que a ocorrência do milagre pela intervenção divina é mais ampla e freqüente do que se tem feito acreditar. Sua fundamentação doutrinária segue à risca a doutrina oficial do catolicismo romano (PRANDI, 1998: 66-67).

A RCC apresenta um mundo encantamento, com curas e milagres. Os carismáticos estão distantes do catolicismo "desencantado" e racionalizado proposto por alguns setores eclesiásticos pelo aggiornamento do Concílio Vaticano II. A RCC trouxe algo que já se encontrava no catolicismo popular e em outras religiões - males de todos os tipos são elevados aos templos pentecostais, aos terreiros afro-brasileiros, aos centros católicos de peregrinação, aos centros kardecistas, às igrejas orientais. Agora, a cura de todos os males está num maior alcance dos católicos, que não precisam mais abandonar a religião "em que se nasceu".

Os carismáticos estão dispostos a brigar no amplo mercado religioso contemporâneo, definindo, inclusive seus inimigos: o espiritismo, as religiões afro-brasileiras, os seguidores do revendo Moon, a Igreja Messiânica Universal, a Seicho-No-Iê, entre outras (PRANDI: 1998, p. 66). Embora não ataquem diretamente os protestantes e pentecostais, há uma preocupação com o avanço da segunda tipologia de cristãos-renova- 
dos. A explicação para o avanço dessas empresas concorrentes é atribuída, dentre outros fatores, à sua presença nos meios de comunicação de massa, o que pode ser ilustrado com o caso da IURD, que ganhou visibilidade de inimigo a ser combatido a partir da aquisição da Rede Record, em 1990.

\section{Considerações finais}

A crise de legitimidade da Igreja Popular e a plausibilidade alcançada pela Renovação Carismática Católica podem ser analisadas a partir daquilo que Daniele Herviu-Léger denominou de "nova religiosidade" centrada no emocionalismo comunitário, como foi descrito inicialmente. Esta ênfase na emoção vem acompanhada de uma repulsa de uma "religião intelectual”. Isto não significa necessariamente um fechamento à modernidade. Os novos movimentos religiosos, como o da RCC, estabelecem um diálogo com o mundo, adotando, inclusive, práticas secularizadas, como Rebanhões, barzinhos de Jesus, rock gospel etc. De acordo com Joanildo Burity, gerou-se um novo rearranjo do campo católico, sobretudo ao final dos anos 1980 e início de 1990. Parte das demandas e do discurso da esquerda teológica foi legitimada e adotada pela nova hegemonia (conservadora) e reescrita num tom espiritualizado. Isto levou a um franco processo de reavaliação da pastoral popular, valorizando mais a dimensão emocional, mística da fé como específico-religioso inegociável em relação a qualquer prática politizada intramundana (BURITY, 1997: 40). 


\section{Referências Bibliográficas}

BERGER, Peter L. O dossel sagrado: elementos para uma teoria sociológica da religião. 3 ed. São Paulo: Paulus, 1985.

. Rumor de anjos: a sociedade moderna e a redescoberta do sobrenatural. Petrópolis: Vozes, 1996.

BOURDIEU, Pierre. A Economia das Trocas Simbólicas. 5. ed., São Paulo: Perspectiva, 1998a.

BURITY, Joanildo. Identidade e Política no campo religioso. Recife: Ed. da UFPE, 1997.

CAMURÇA, Marcelo Ayres. "A sociologia da religião de Daniele HerviuLéger: entre a memória e a emoção". In: TEIXEIRA, Faustino (org.). Sociologia da Religião: enfoques teóricos. Petrópolis: Vozes, 2003, p. 249-270.

CARRANZA, Brenda. Renovação Católica Carismática: origens, mudanças e tendências. 2 ed. Aparecida-SP: Editora Santuário, 2000.

CARVALHO, José Jorge de. "Religião, mídia e os predicamentos da convivência pluralista: uma análise do evangelismo transnacional norte-americano.” In: MOREIRA, Alberto da Silva. Sociedade Global: cultura e religião. Petrópolis: Vozes; São Paulo: Universidade São Francisco, 1998.

. Uma querela de espíritos: para uma crítica brasileira do suposto desencantamento do mundo moderno. Revista Sociedade e Estado, v. XIV, n. 1, jan./jun. 1999, p. 63-87.

CASTRO, Ruy (org.). Flor de Obsessão: as 1000 melhores frases de Nelson Rodrigues. São Paulo: Companhia das Letras, 1997.

CERIS. Desafios do catolicismo na cidade: pesquisa em regiões metropolitanas brasileiras. São Paulo: Paulus, 2002. 
GUERRA, Lemuel. Competição, demanda e a dinâmica da esfera da religião no Nordeste do Brasil. Recife, 2000. Tese (Doutorado em Sociologia) - UFPE.

HERVIU-LÉGER, Danièle. Representam os surtos emocionais contemporâneos o fim da secularização ou o fim da religião? Religião e Sociedade, Rio de Janeiro, v. 18, n. 1, agosto 1997, p. 31-47.

LOVY, Michel. A guerra dos deuses: religião e política na América Latina. Rio de Janeiro: Vozes, 2000.

MIRANDA, Júlia. Carisma, sociedade e política: novas linhagens do religioso e do político. Rio de Janeiro: Relumé Dumará; Núcleo de Antropologia Política, 1999.

MACHADO, Maria das Dores Campos. Carismáticos e pentecostais: adesão religiosa na esfera familiar. Campinas-SP: Autores Associados; São Paulo: ANPOCS, 1996.

MARX, Karl. “Prefácio”. Para a Crítica da Economia Política. In: Manuscritos Econômico-Filosóficos. São Paulo: Abril Cultural, 1978.

ORO, Ari Pedro. Avanço Pentecostal e Reação Católica. Petrópolis: Vozes, 1996.

ORO, Ari Pedro; CORTEN, André; DOZON, Jean-Pierre (orgs.). Igreja Universal do Reino de Deus: os novos conquistadores da fé. São Paulo: Paulinas, 2003 (Coleção religião e cultura).

ORTIZ, Renato. A moderna tradição brasileira: cultura brasileira e indústria cultural. 5 ed. São Paulo: Brasiliense, 2001.

PIERUCCI, Antônio Flávio e PRANDI, Reginaldo. A Realidade Social das Religiões no Brasil. São Paulo: Editora Hucitec, 1986.

PIERUCCI, Antônio Flávio. A encruzilhada da fé. Folha de São Paulo. São Paulo, 19 de maio de 2002, p. 07 (Mais!). 
PRANDI, Reginaldo. Um sopro do Espírito: a renovação conservadora do catolicismo carismático. 2 ed. São Paulo: Edusp, 1998.

STEIL, Carlos Alberto. A Igreja dos Pobres: da Secularização à Mística. Religião e Sociedade, Rio de Janeiro, v. 19, n. 2, out./1998, p. 61-76.

THEIJE, Marjo de. Tudo o que é de Deus é bom: uma antropologia do catolicismo liberacionista em Garanhuns, Brasil. Recife: Fundação Joaquim Nabuco/Editora Massangana, 2002. 